\title{
Chiari IV malformation: correcting an over one century long historical error
}

\author{
R. Shane Tubbs ${ }^{1,2,3,4,5}$ - Amin Demerdash ${ }^{1}$. \\ Payman Vahedi $^{6}$ - Christoph J. Griessenauer ${ }^{1}$. \\ W. Jerry Oakes ${ }^{1}$
}

Received: 1 May 2015 / Accepted: 22 May 2015 /Published online: 7 June 2015

(C) Springer-Verlag Berlin Heidelberg 2015

\section{Background}

Hans Chiari (1851-1916) (Fig. 1) gave the first detailed illustrations of what is now termed the Chiari malformations. In 1891, he described several congenital anomalies affecting the cerebellum due to hydrocephalus, and this paper listed three different types of abnormalities [1]. Four years later, in 1895, Chiari wrote a second paper (Fig. 2) that described the type IV malformation in two patients [2].

\section{Original description by Hans Chiari}

Fourth type

Cerebellar hypoplasia without herniation of posterior fossa content into the spinal canal

R. Shane Tubbs

shane.tubbs@childrensal.org

1 Pediatric Neurosurgery, Lowder 400, Children's of Alabama, 1600 7th Ave South, Birmingham, AL 35233, USA

2 College of Health Sciences, Samford University, Birmingham, AL, USA

3 Centre of Anatomy and Human Identification, University of Dundee, Dundee, UK

4 Department of Anatomy, St. George's University, True Blue, Grenada

5 Department of Neurosurgery, Vanderbilt University, Nashville, TN, USA

6 Department of Neurosurgery, Tehran Medical Branch, Islamic Azad University of Medical Sciences, Tehran, Iran
Here, I describe two cases of cerebellar changes secondary to congenital hydrocephalus of the cerebrum without herniation of posterior fossa contents into the spinal canal as encountered in the other types.

A. Significant hypoplasia of the entire cerebellum. Rolling of the interior vermis. Indentation of the dorsal wall of the fourth ventricle.

Twenty-third case: Two-day-old girl. Department of Surgery at the Kaiser Franz Joseph pediatric hospital under Prof. Dr. Bayer. Dissection on March $19^{\text {th }}, 1892$ (30 $\mathrm{h}$ post mortem).

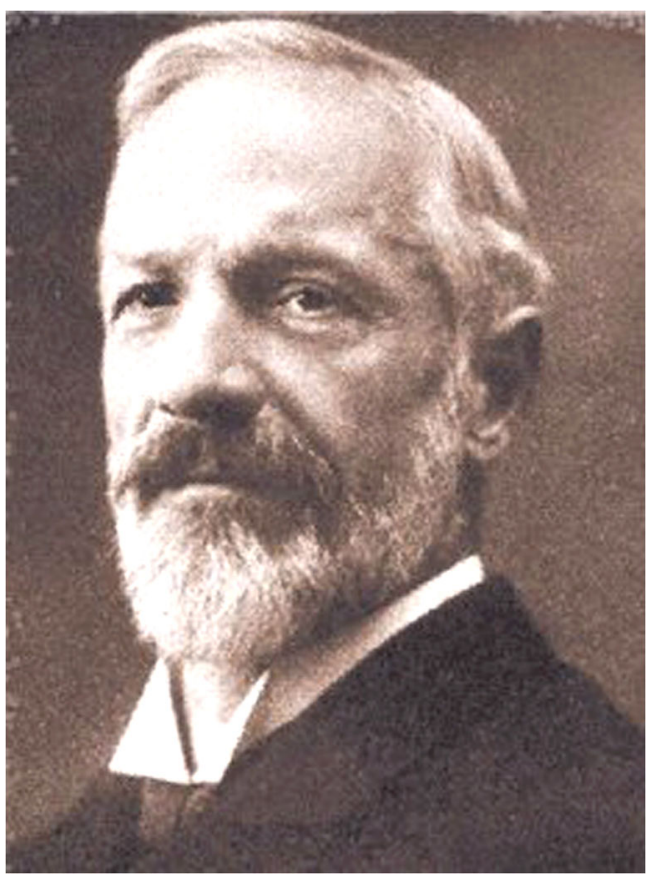

Fig. 1 Hans Chiari's photograph 
Fig. 2 First page from Chiari's 1895 Über Veränderungen des Kleinhirns, des Pons und der Medulla Oblongata infolge von congenitaler Hydrocephalie des Grosshirns.Denkschr der Kais Akad Wiss Wien math. Naturw. 63:71-116
ÜBER

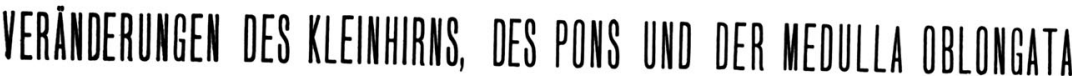

IN FOLGE VON

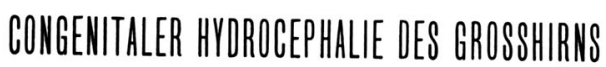

voN

DR. H. CHIARI

PROFESSOR DER PATHOLOGISCHEN ANATOMIE AN DER DEUTSCHEN UNIVERSITÃT IN PRAG.

(ขTit 8 Jafeln.)

VORGELEGT IN DER SITZUNG VOM 7. FEBRUAR 1895.

In der folgenden Abhandlung will ich die Resultate einer über mehrere Jahre ausgedehnten, systematischen Untersuchung vorlegen, welche sich mit dem Studium der Veränderungen der Lage, der Architektur und der Textur des Kleinhirns, des Pons und der Medulla oblongata beschäftigte, insoweit solche Veränderungen durch congenitale Hydrocephalie des Grosshirns hervorgerufen werden können.

Wie ich schon seinerzeit in einer vorläufigen Mittheilung über dieses Thema' zu bemerken Gelegenheit hatte, haben diese Veränderungen bis jetzt eigentlich gar keine Berücksichtigung erfahren. Doch aber erscheinen sie mir von grossem Interesse, und zwar einerseits deswegen, weil dadurch gezeigt wird, wie bedeutend die Gebilde des Hinter- und Nachhirns durch congenitale Hydrocephalie des Grosshirns in ihrer Entwicklung beeinflusst werden können, andererseits aber auch aus dem Grunde, weil damit vielleicht in manchen Fällen von Hydrocephalie etwaige klinische Erscheinungen seitens des Pons, der Medulla oblongata oder auch des Kleinhirns ihre Erklärung finden könnten.

In meiner vorläufigen Mittheilung zählte ich drei Typen von Veränderungen auf, nämlich

I. Die Verlängerung der Tonsillen und der medialsten Theile der Lobi inferiores des Kleinhirns zu zapfenförmigen Fortsätzen, welche die Medulla oblongata in den Wirbelcanal begleiten,

II. Die Verlagerung von Theilen des Kleinhirns in den erweiterten Wirbelcanal innerhalb des verlängerten, in den Wirbelcanal hineinreichenden vierten Ventrikels und

III. Die Einlagerung nahezu des ganzen, selbst hydrocephalischen kleinhirns in eine Spina bifida cervicalis.

Ich illustrirte diese drei Typen damals durch einzelne Beispiele.

' Uber Veränderungen des Kleinhirns in Folge von Hydrocephalie des Grosshirns. Deutsche med. Wochenschr. 1891, Nr. 4‥
Clinical diagnosis: Encephalocele occipitalis amputata. Encephalitis. Sclerema.

Medical history: The encephalocele consists of a cylindrical, broad based, $6 \mathrm{~cm}$ long, and $3 \mathrm{~cm}$ wide skin sac. The sac has an ulcerated opening measuring about $8 \mathrm{~cm}$. Through this opening, another, $4 \mathrm{~cm}$ wide inner sac, similarly ulcerated at the end, protrudes. That second, inner sac is made up of meninges with longitudinally oriented folds, almost of the size of a little finger. The inner sac communicates with the intracranial compartment through a $1 \mathrm{~cm}^{2}$ wide opening located just below the posterior fontanel. The outer sac is contingent with the scalp. In surgery the inner sac was disconnected and resected at the intracranial opening and closed with the excess skin overlying it. The patient passed $36 \mathrm{~h}$ after surgery.

Pathological-anatomical diagnosis: Meningitis cerebralis suppurativa et suppuratio in ventriculis cerebri ex ulceratione hydrencephaloceles occipitalis (horas XXXVI ante mortem amputatae). Dilatatio congenita ventriculorium cerebri. Pneumonia lobularis bilateralis. Sclerema textus adipose subcutanei.

Dissection of the central nervous system: The child's head is disproportionally large compared to its height $(47 \mathrm{~cm})$, just a little more narrow. Hair shaved. Inferior to the posterior fontanel there is a skin bulge measuring $6 \mathrm{~cm} \times 3 \mathrm{~cm} \times 2 \mathrm{~cm}$ with a $6 \mathrm{~cm}$ long closed incision at the top. The edges are edematous and erythematous. The soft skull is ecchymotic, pale, in the area of the bulge edematous, serous, and purulent. Circumferentially the skull measures $27 \mathrm{~cm}$. The sutures are split. The sagittal suture is $0.5 \mathrm{~cm}$ wide. The anterior fontanel is larger measuring $4 \mathrm{~cm}$ in length and $2.5 \mathrm{~cm}$ in width. The posterior fontanel is normal in size. The skull bones are fairly rigid. In the squama ossis occiptialis, $2 \mathrm{~cm}$ inferior to the posterior fontanel, there is an opening of the size of the nail of a small finger. The opening is surrounded by the split of the processus sagittalis major of the pachymenix. Through that opening a hemorrhagic and necrotic mass of inner meninges and brain parenchyma are extruding. In the sinus durae matris 
there is dark, liquid, and also freshly coagulated blood. The sinus sagittalis major is split into two sinuses from the area of the posterior fontanel that diverge to form the sinus transversi. The tentorium cerebelli is narrow, the processus falciformis minor is absent, the posterior fossa is small. The inner surface of the skull base has deep impressiones digitatae. The foramen occipital magnum is remarkably narrow. The inner meninges are pale and infiltrated by serous and purulent liquid.

The gyri and sulci of the cerebrum appear normal. The lateral ventricles and third ventricle are enlarged and contain serous and purulent liquid. The brain matter is pale, moist, and soft. Originating from the precuneus are two processes of brain matter that contain the occipital horns and plexus choroidei of the lateral ventricles and protrude through the previously mentioned opening.

The cerebellum is only half the size of a normal cerebellum. It is $3.5 \mathrm{~cm}$ wide and $2 \mathrm{~cm}$ long. The largest diameter from the upper to the lower surface is $3 \mathrm{~cm}$. It is asymmetric with the left hemisphere significantly smaller than the right. The lobi superiores, posteriores et inferiores are easily distinguished, the tonsils and flocculi are rudimentary. The inferior vermis is more prominent and the incisura marginalis posterior is absent. The pons and medulla oblongata are 14 and $11 \mathrm{~mm}$ long, respectively. Both are thin.

A median sagittal section of the cerebellum, pons, medulla oblongata, and upper cervical spinal cord (Fig. 3 and Cover figure) shows unusual rolling of the lower portion of the arbor vitae resulting in a deep location of the pyramis (a), high location of the uvula (b), and location of the nodulus (c) of the inferior vermis on the upper end of the rolling of the arbor vitae. The dorsal wall of the fourth ventricle (d) is bowed due to the rolling and the velum medullare posterius (e) is very long. The entry of the tela choroidea ventriculi IV is well demarcated (f) and at the usual location. The ponticuli (g) are longer and thicker, as is the velum medullare posterius. The corpora dentata cerebelli are smaller, otherwise normally shaped. The pons and medulla are normal.

The spinal cord is of dense consistency. The inner meninges of medulla oblongata, pons, and cerebellum are not purulent.

Microscopic examination of the encephalocele occipitalis, vermis, pons, medulla oblongata, corpus dentatum of the right cerebellar hemisphere, the fifth cervical segment, fifth and ninth thoracic segments, and third segment of the spinal cord is performed after solidification with liquor mülleri.

The inner sac of the encephalocele has two layers. The outer layer is highly vascularized and hemorrhagic as are the inner meninges while the inner layer is of sclerotic brain matter. The latter makes up the previously

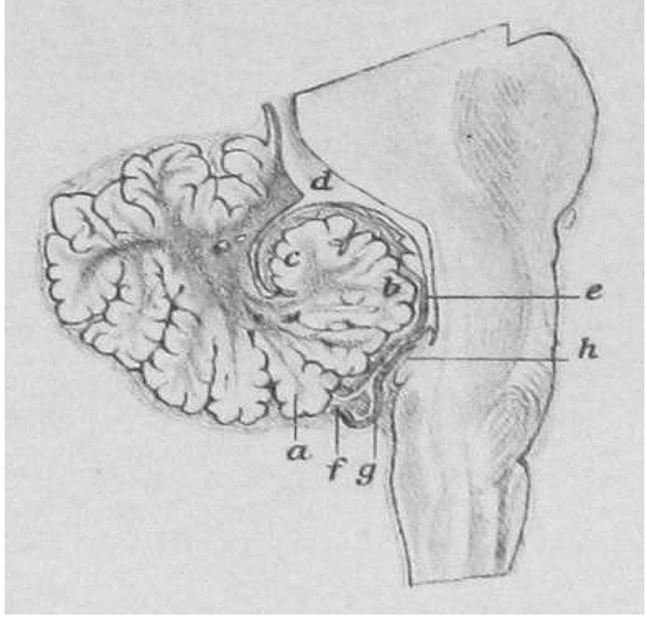

Fig. 3 and Cover figure Original drawing from 1895 of the type IV malformation from Über Veränderungen des Kleinhirns, des Pons und der Medulla Oblongata infolge von congenitaler Hydrocephalie des Grosshirns. Denkschr der Kais Akad Wiss Wien math. Naturw. 63:71116. Chiari notes the unusual rolling of the lower portion of the arbor vitae resulting in a deep location of the pyramis $(a)$, high location of the uvula $(b)$, and location of the nodulus $(c)$ of the inferior vermis on the upper end of the rolling of the arbor vitae. The dorsal wall of the fourth ventricle $(d)$ is bowed due to the rolling and the velum medullare posterius $(e)$ is very long. The entry of the tela choroidea ventriculi IV is well demarcated $(f)$ and at the usual location. The ponticuli $(g)$ are longer and thicker, as is the velum medullare posterius. The corpora dentata cerebelli are smaller, otherwise normally shaped. The pons and medulla are normal

mentioned longitudinally oriented folds. The inner surface of the sac is lined with cylindrical epithelium.

The vermis, pons, and medulla oblongata are examined using the right half of the section. The vermis has normal texture. Its cortex has an external granular layer, a molecular layer, and an inner granular layer. There are numerous Purkinje cells. The medulla is mostly black on copper hematoxylin stain. The pons and medulla oblongata are normal. Only the pyramids are devoid of medullary substance. The fourth ventricle is lined with normal epithelium. The elongated velum medullare

Table 1 Salient features of the Chiari IV malformation

Occipital encephalocele (through the posterior fontanele) with occipital lobe and horn as contents

Splitting of the superior sagittal sinus around the occipital encephalocele Hydrocephalus

Cerebellar hypoplasia but NOT aplasia

Absence of falx cerebelli

Narrowed tentorium cerebelli

Small posterior fossa

Narrow foramen magnum

Elongated inferior medullary velum "Rolled" inferior vermis

Indentation of the posterior wall of the fourth ventricle 
posterius and taenia plexus chorioidei ventriculi IV are sclerotic.

The corpus dentatum cerbelli has prominent folding and numerous multipolar ganglion cells. The medulla spinalis has a mild dilatation of the central canal lined with epithelium and the pyramidal tract is devoid of medullary substance.

The surgical perspective of Chiari's case was published by Bayer [3] in 1892. Table 1 lists the salient features of the Chiari IV malformation as originally described. A few decades before Chiari's work on the conditions that eventually carried his name, French anatomist and pathologist, Jean Cruveilhier (1791-1874), gave a detailed illustration of what some [4] later believed to be the Chiari IV malformation.
However, Cruveilhier's drawings of this specimen showed hypoplastic cerebellar hemispheres in addition to a funnelshaped posterior fossa (Fig. 4) [4]. Without the primary finding of an occipital encephalocele, the case of Cruveilhier's is obviously not a Chiari IV malformation. Other authors have cited features of the Chiari IV malformation that include enlargement of the fourth ventricle without any abnormalities in the third or lateral ventricles and a pons that is atrophic and described as having a "pigeon breast" shape [5]. None of these findings is consistent with Chiari's original description. Raimondi documented the cases of three children who presented with bilateral vocal cord paralysis; the patients had a "very characteristic arteriographic pattern," which was consistent with the features of Chiari IV malformation. On arteriogram,
Fig. 4 Illustration from Cruveihier's Anatomie pathologique du corps humain published in 1828. Although later authors referred to this as an illustration of what would become known as the Chiari IV malformation, it is not

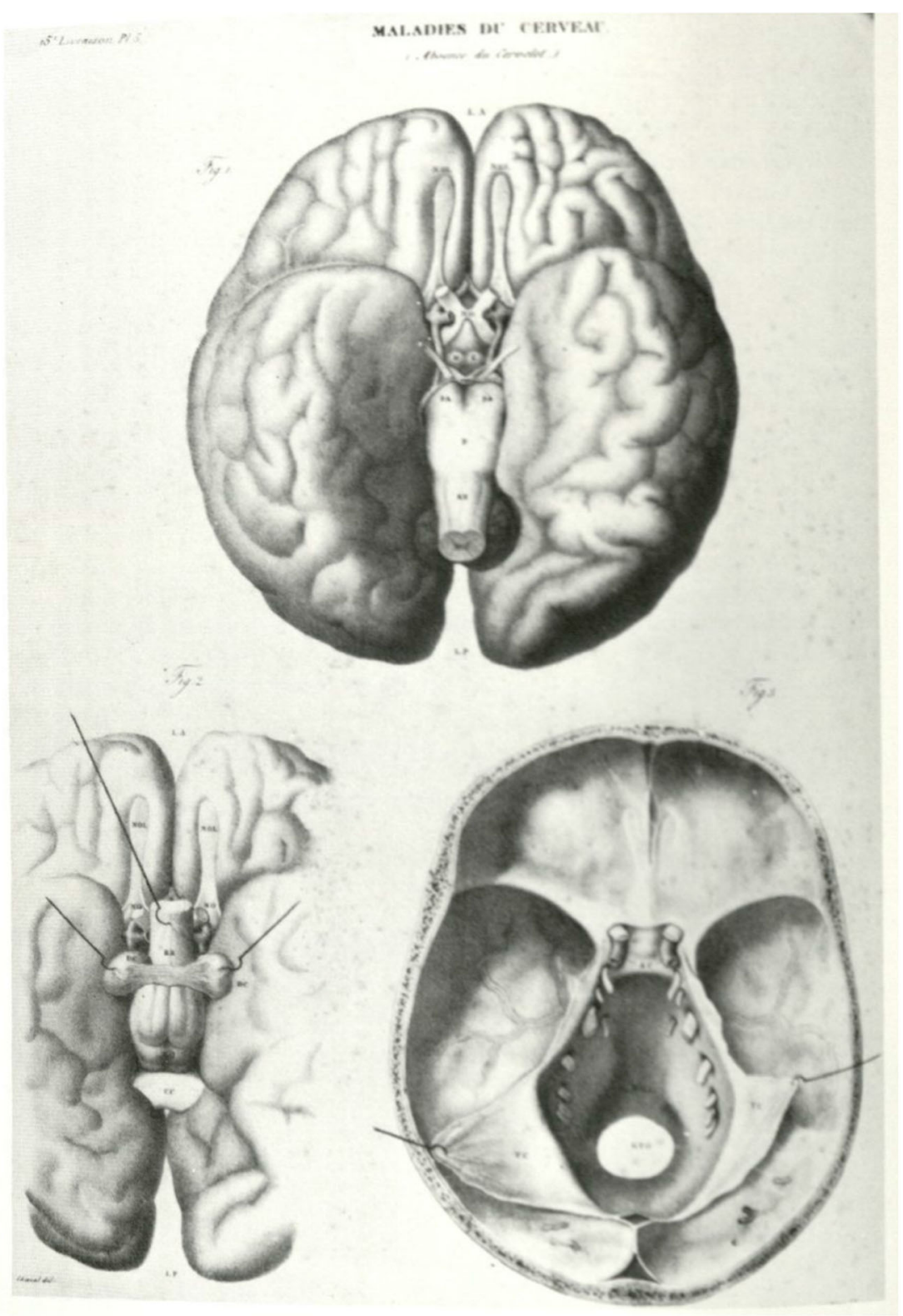


the basilar and vertebral arteries showed filling defects that can be correlated with the massive enlargement of the pontine and medullary cisterns, the fourth ventricle and the cisterna magna that appeared on the pneumoencephalogram. Vertebral artery arteriography showed a sharp angulation of the basilar artery forming the so-called "pigeon-breasted deformity" that pointed anteriorly, it also showed that the vertebral arteries' main trunks curved slightly posteriorly and then made a sharp angulation to join each other below the basilar artery's trunk. The cerebellar hypoplasia and the dilatation of the fourth ventricle also had a great effect on the posterior inferior cerebellar arteries and the choriodal point could not be identified, and there was no clear distinction between the tonsillar and vermian branches [4]. Again, these descriptions have nothing to do with the Chiari IV malformation.

\section{Confusion}

Due to the continued misuse of the term Chiari IV malformation, several reports have entirely misunderstood and misinterpreted the definition of this pathology and have, therefore, made incorrect statements about the malformation. For example, some have stated, "most infants born with type IV Chiari malformation do not survive [6]." Some go on to say that this is the "most severe" form of Chiari malformation [7]. Referring to the Chiari IV malformation, one author stated, "The cerebellar tonsils are located further down the spinal canal than they normally would be, part of the cerebellum is herniated, and some parts of the skull and spinal canal may be visible [8]." The already confused and incorrect use of the term Chiari IV malformation has been convoluted even more as some have reported a similarity between this malformation and the Dandy-Walker malformation or variant $[4,9]$. Obviously, the above noted examples are erroneous and are not based on the original description by Chiari.

\section{Conclusions}

Since the original paper, we were unable to find a single report in the literature that used the term "Chiari IV malformation" and that was consistent with Chiari's description of the type IV malformation. As Chiari depicted (Fig. 2) only the posterior fossa contents in his 1895 tome, this may have lead many to misinterpret his findings and propagate the idea that the main feature of the Chiari IV malformation is cerebellar hypoplasia [10]. The primary feature of this malformation, from hence forward and in line with Chiari's original description, should be an occipital encephalocele with supratentorial contents.

\section{References}

1. Chiari H (1891) Über veränderungen des kleinhirns infolge von hydrocephalie des grosshirns. Dtsch Med Wochenschr 17:11721175

2. Chiari H (1895) Über veränderungen des kleinhirns, des pons und der medulla oblongata infolge von congenitaler hydrocephalie des grosshirns. Denkschr der kais akad wiss wien math. Nature 63:71116

3. Bayer: Zur Technik der Operation der Spina bifida und Encephalocele (1892) Prag med Woch 4:346

4. Raimondi AJ (1972) Pediatric neurosurgery. Saunders, Philadelphia, pp 235-237, 339-343

5. Brownlee R, Myles T, Hamilton MG (1997) The Chiari III and IV malformations. In: Anson JA, Benzel EC, Awad IA (eds) Syringomyelia and the Chiari malformations. AANS, Park Ridge, pp 88-89

6. Anonymous (2015) Chiari malformation. http://www. gillettechildrens.org/conditions-and-care/chiari-malformation/

7. Highsmith JM (2015) Chiari malformation: a basic overview http:// www.spineuniverse.com/conditions/spinal-disorders/chiarimalformation-basic-overview

8. Vanaclocha V (2015) The Chiari malformations. http://www. neuros.net/en/chiari malformations.php

9. Barkovich AJ (1995) Pediatric neurosurgery, 2nd edn. Raven, New York, pp 249-453

10. Tekin D, Uysal S, Iyigun O (2002) Primary cerebellar agenesisChiari IV malformation. OMU Tip Derg 19:213-216 